\title{
KALBA
}

\section{PARLAMENTINIO DISKURSO ANALIZE்: KREIPIMOSI RAIŠKOS KAITA}

Zoja Petrošıūté

Vilniaus universitetas

Vilnius University

Universiteto g. 3, LT-01513 Vilnius

El.paštas zoja.petrosiute@hotmail.com

\section{Santrauka}

Straipsnyje aptariama kreipimosi raiškos kaita Lietuvos parlamentiniame diskurse 1923, 1990 ir 2013 metais. Tema nagrinejjama remiantis tokia prielaida: keičiantis kreipimosi raiškai, t. y. demokratejjant kalbai viešojoje vartosenoje (televizijoje, spaudoje, radijuje ir pan.), kreipimosi raiška keičiasi ir itin oficialioje viešojoje erdveje Seime. Atlikta analize rodo, jog 2013 metais politiku kalba, palyginti su 1923 ir 1990 metų kalba, tapo demokratiškesnè, per kreipinius dažniau užmezgamas tiesioginis, asmeniškesnis santykis su adresatu, ‘̇ adresata nevengiama kreiptis ịvardžiu tu, 2013 metu kreipimosi tendencijos yra perkeliamos iš neoficialios aplinkos ị oficialią viešają erdvę.

Reikšminiai žodžiai: parlamentinis diskursas; adresato įvardijimas; kreipiniai; ịvardžiai; politikų kalba.

\section{Ivadas}

Adresanto parinkti kreipimosi būdai suteikia nemažai informacijos ne tik apie adresantą ir adresatą, jų santykius, kreipimosi raišką, bet ir 
daug pasako apie visuomenę, kurioje jie yra vartojami: kreipimosi raiškos kaita rodo, jog ir pačioje visuomenèje politiniu, ekonominiu, kultūriniu ir socialiniu atžvilgiais vyksta santykių pokyčiai. Kreipimosi žodžiai atspindi kultūros vertybes ir yra rodiklis socialinių bei politinių pokyčių, turinčių įtakos komunikantų santykiams ir kalbinei raiškai ${ }^{1}$. Todèl kreipimosi raiška ir sulaukia daug užsienio bei Lietuvos tyrẻjų dėmesio. Kreipimosi žodžiais (toliau - KŽ), t. y. leksinėmis priemonemis, kuriomis įvardijamas adresatas, ne tik pavadinamas asmuo, tokiu būdu visada yra perduodama daugiau informacijos apie save ir kitą asmenį negu atrodo iš pirmo žvilgsnio - mandagumo žodžiais išreikštas asmens įvardijimas iš tikrụjų reiškia ir subjektyvų požiūrị i jij ${ }^{2}$. Taip pat KŽ vartosena rodo adresanto ir adresato tarpusavio santykių laipsnį, atskleidžia šių santykių bruožus ${ }^{3}$. Keičiantis santykiui, keičiasi ir KŽ vartosena. Tyrimai rodo, kad viešojoje vartosenoje (televizijoje, radijuje) plinta neformalūs adresato ịvardijimo būdai - antrojo asmens vienaskaitinis ịvardis $t u$, antrojo asmens vienaskaitos veiksmažodžiai, vardas ${ }^{4}$, tačiau kalbininkai iki šiol dar nebuvo atlikę specialaus tyrimo, kaip keičiasi kalba ir kaip neformalūs kreipiniai pasireiškia itin oficialiame viešajame diskurse, tokiame kaip politikų kalba per Seimo posėdžius. Laura Butkute் ${ }^{5}$, savo tyrimui

1 Norrby, C., Warren, J. Address in world perspective. Australian of Applied Linguistics. 2006, 29(2). Prieiga per internetą: http://www.highbeam.com/ doc/1G1-156136251.html.

2 Kniūkšta, P. Administracine kalba ir jos vartosena. Vilnius: Lietuvių kalbos institutas, 2005, p. 138.

3 Tomiczek, E., Kucharska, E. Die konventionalisierte Höflichkeit: einige Überlegungen zur polnischen und deutschen Epistolographie. Studien zur Deutschen und Niederländischen Sprache und Kultur. Warszawa: Universität Warschau, Germanistisches Institut, 1996, p. 267.

4 Marcinkevičienè, R. Užsakomųų reklaminių straipsnių tarpasmeninès funkcijos raiška. Respectus philologicus. Nr. 6(11) (2004), p. 56-63; Čepaitienè, G. Lietuviu kalbos etiketas: semantika ir pragmatika. Šiauliai: Šiaulių iniversiteto leidykla, 2007, p. 79; Girčienè, J. Adresato ịvardijimo raida. Žmogus kalbos erdveje. 2011, Nr. 6, p. 1.

5 Butkutè, L. Frazeologinių junginių stilistinè raiška Seimo stenogramose. Parlamento studijos. Nr. 8 (2009), p. 45. 
naudojusi Seimo posėdžių stenogramas, pastebejjo, jog politikų kalba skiriasi nuo buitinès, yra oficialesnè, sausesnè.

Straipsnio objektas - kreipimosi žodžiai, t. y. leksemos, kuriomis adresantas kreipiasi $\mathfrak{i}$ adresatą: ivvardija ji, nurodo $\mathfrak{i}$ ji, t. y. kaip nors užmezga santykị su adresatu - tiesiogiai arba netiesiogiai. Straipsnio tikslas - ištirti kreipimosi raišką skirtingų laikotarpių (1923, 1990 ir 2013 m.) Lietuvos Respublikos Seimo posėdžiuose. Analizuojamos kiekvienų metų stenogramos, užrašytos per tris savaites prieš Seimo sesijos pabaigą (per pavasario sesiją) ir per tris savaites prasidejus sesijai (per rudens sesiją). Keliami keli svarbiausi tyrimo klausimai: kokios KŽ vartosenos tendencijos vyravo politiniame diskurse 1923 ir 1990 metais ir kaip jos pakito iki 2013 metų? Kokios KŽ tendencijos vyrauja šiuolaikiniame politiniame diskurse ir kas lemė anksčiau bei kas lemia dabar vienokią ar kitokią KŽ vartoseną? Kokią komunikacinę distanciją ankstesniais dešimtmečiais kūrè politikai, kreipdamiesi vienokiu ar kitokiu kreipiniu, ir kokia komunikacinè distancija kuriama šiuolaikiniame politiniame diskurse?

Užsienio mokslininkus jau seniai domina kreipiniai, pavyzdžiui, 1960 metais Rogeris Brownas ir Albertas Gilmanas aprašè antrojo asmens įvardžių teoriją ${ }^{6}$ Vèliau pasirodè nemažai kitų mokslinių darbų, aptariančių kreipinius kasdienejje buitinėje kalboje ir parlamentiniame diskurse. Tyrejjai itin aktyviai analizuoja kreipinius politikų kalboje. Keli pavyzdžiai: lenkų mokslininkai Adamas Jaworskis ir Dariuszas Galasinskis tyrė Lecho Wałęsos ir kitų kelių politikų kalbą nuo 1988 iki 1995 metų: jie analizavo, kaip politikai kreipiasi vienas j̣ kitą ir kaip kreipiniai formuoja politinę erdvę viešajame diskurse ${ }^{7}$. JAV mokslininkas Johnas Oddo 2011 metais tyrè JAV prezidentų Franklino D. Roo-

6 Brown, R., Gilman, A. The pronouns of power and solidarity. Sociolinguistics: the essential readings. Edited by G. Richard Tucker, Ch. Bratt Paulston. Malden, 2003, p. 157-175.

7 Galasinski, D., Jaworski, A. Vocative address forms and ideological legitimization in political debates. Discourse Studies. Vol. 2 no. 1 (2000), p. 35-53. 
sevelto ir Georgéo W. Busho 4 viešąsias kalbas - jam buvo įdomu, kaip šie prezidentai vartoja ịvardžius - aprèpiamajj mes ir jie savo kalbose, siekdami manipuliuoti publika ${ }^{8}$.

Lietuvių kalbininkai taip pat domisi KŽ vartosena: Jurgita Girčienè 2009 metais domejjosi daugiskaitinių ir vienaskaitinių kreipimosi formų konkurencija viešojoje sakytinèje vartosenoje ${ }^{9}$. Giedrè Čepaitienè 2007 metais aprašè participinių ívardžių ir nominatyvinių adresato ivvardijimų vartoseną kai kuriose viešosios sakytinès kalbos srityse ${ }^{10}$. Mokslininkai domisi ne tik kreipinių vartosena, bet ir kreipinių kaita, pavyzdžiui, Jurgita Girčienė 2011 metais aptarè tarybinio (1967-1987), pereinamojo (1988-1992) ir dabartinio (1993-2011) laikotarpių televizijos laidų kreipinių kaitą ${ }^{11}$. Tyrimo duomenys parodè, jog dabartiniu metu televizijos laidose dalyviai vieni $\mathfrak{i}$ kitus kreipiasi familiaresniais adresato įvardijimais - vardais, ịvardžiu $t u$.

Šiame straipsnyje pasirinkta ištirti kelių Seimo darbo laikotarpių 1923, 1990 ir 2013 metų - kreipinius, kad būtų galima atlikti kokybinę ir lyginamąją šių laikotarpių kreipimosi tendencijų analizę. Tiriamoji medžiaga - 43 Seimo posėdžių stenogramos. Medžiaga kokybinei analizei buvo gauta iš šių stenogramų - apskaičiuotas kreipimosi žodžių dažnumas, vartojimo tendencijos, buvo tiriama sakinio, kuriame pavartotas kreipinys, semantika, t. y. kada vartojamas vienas ar kitas kreipinys, ką jis reiškia konkrečiame kontekste. Toliau pateikiama KŽ analizè. Kiekvienas kreipimosi būdas aptartas atskiruose skyreliuose: pateikiami ir išanalizuojami dažniausiai pasitaikę kreipiniai, pavyz-

8 Oddo, J. War legitimation discourse: representing 'Us' and 'Them' in four US presidential addresses. Discourse Society. Vol. 22, no. 3 (2011), p. 287-314.

9 Girčienè, J. Daugiskaitinių ir vienaskaitinių kreipimosi formų konkurencija viešojoje sakytinejje vartosenoje (sociolingvistinis aspektas). Kalbos kultūra. T. 82 (2009), p. 214-233.

${ }^{10}$ Čepaitienè, G. Lietuviu kalbos etiketas: semantika ir pragmatika. Šiauliai: Šiaulių universiteto leidykla, 2007.

${ }^{11}$ Girčienè, J. Adresato i̦vardijimo raida. Žmogus kalbos erdvëje. 2011, Nr. 6, p. $612-621$. 
džiai paimti iš stenogramų. Prie kiekvieno skyrelio yra po lentelę su kiekybiniais duomenimis, t. y. joje pateikiamas kreipinių pavartojimo skaičius.

1. Kreipimasis daiktavardiniu kreipiniu. Daiktavardiniu kreipiniu parlamentiniame diskurse dažniausiai nurodomos asmens einamos pareigos, profesija, mokslinis vardas. Toks kreipinys paprastai sudarytas iš vieno ar kelių daiktavardžių. Dažniausiai Seimo Pirmininkas 1923 metais kreipèsi ì politikus netiesiogiai daiktavardiniu ìvardijimu kviesdamas juos kalbèti per pavasario ir rudens sesijas. Netiesioginiu kreipiniu eina trečiojo asmens forma, kai apie adresatą adresantas kalba tarsi apie pašalini asmeni. Tokiu būdu adresatai buvo pristatomi ir kitiems - pasakytos jų pareigos - taip kiekvienas asmuo išskiriamas iš kitų kolegų. Prieš žodi ministras kartais buvo pridedama kilmininko linksnio konstrukcija, kuria patikslinama, kokios srities ministras yra kviečiamas kalbėti (1 pvz.). Tokie kreipiniai labai formalūs ir neutralūs. Kartais prieš pareigų pavadinimą buvo vartojamas mandagusis kreipinys ponas (2 pvz.). Pasak J. Girčienès, toks kreipinys tarpukariu buvo iprastas ${ }^{12}$. Tiesiogiai $\mathfrak{i}$ asmeni kreiptasi tada, kai adresantas jam perduodavo informaciją. Tiesioginis kreipinys - tai adresato ịvardijimas antrojo asmens forma. Antrosios nepriklausomybès laikotarpiu ir 2013 metais politikai vieni ị kitus dažniausiai kreipdavosi pareigų pavadinimu (3 ir 4 pvz.):

1) Žodi gauna Krašto Apsaugos Ministeris (posèdžio pirmininkas Justinas Staugaitis, 1923 m. rugsèjo 18 d., 25 posédis, rudens sesija);

2) Aš prie papildomų žinių ir einu, ponas pirmininke (Pranas Radzevičius Justinui Staugaičiui, 1923 m. liepos 13 d., 14 posédis, pavasario sesija);

3) Ministre, aš, matyt, ne taip suformulavau klausimą. Aš norèjau paklausti, ar jūs nemanote, kad šita ìstatymą reikia priimti anksčiau, ne

12 Ten pat, p. 1. 
nuo sausio 1 d., bet anksčiau? (Aloyzas Sakalas Algirdui Dobravolskui, 1990 m. rugsèjo 21 d., 12 posédis, rudens sesija);

4) Premjere, pavasario sesijos pradžioje mes frakcijoje buvome pasikvietę ir labai gražiai pasikalbejome su socialinès apsaugos ir darbo ministre ponia A. Pabedinskiene apie vaiku globos istaigu pertvarka ir rengiama strategija (Dalia Kuodytė Algirdui Butkevičiui, 2013 m. rugséjo 10 d., 75 posédis, rudens sesija).

Taip pat 1990 ir 2013 metais Seimo nariai kartais vieni ị kitus, prieš suteikdami naują informaciją, kreipdavosi mandagiu kreipiniu kolegos / kolega (5 pvz.). Tokiu kreipiniu adresantas apibrèžia kolegiškus santykius, ịvardija juos, taip dažnai kreiptasi ị vieną asmenị (5 pvz.):

5) Dékoju, kolege, už palaikymą (posèdžio pirmininkas Vydas Gedvilas Rimai Baškienei, 2013 m. birželio 13 d., 62 posédis, pavasario sesija).

Kartais 1990 ir 2013 metais i adresatą kalbetojas kreipdavosi jo moksliniu vardu (6 pvz.), tačiau tokiu kreipiniu buvo įvardijami tik asmenys, atėję ị vieną posėdị, dažniausiai ne Seimo nariai. Tokiu būdu su adresatu išlaikomas pagarbus atstumas, oficialumas, jis išskiriamas iš kitų:

6) Atleiskite, profesoriau, aš mat nepatikslinau (Vytautas Landsbergis Kazimierui Antanavičiui, 1990 m. liepos 26 d., 114 posédis, pavasario sesija).

Netiesioginiu kreipiniu, reiškiančiu skyriaus, grupès ar partijos pavadinimą, kreipiamasi ì grupę asmenų. Adresantas nevartoja tiesioginio kreipinio, nes nèra $\mathfrak{i}$ ką kreiptis tiesiogiai, šiuo atveju reikètų konkretaus adresato, o jeigu jis ir yra, greičiausiai tai tos grupés ar skyriaus atstovas, ir kalbètojas $\mathfrak{i}$ ji kreipiasi kaip i visą grupę. Dažniausiai, kai kreipiamasi ị daugumą tokiu kreipiniu, norima ko nors paklausti (nuomonès, nutarimo) arba pakviesti (kalbèti, daryti pertrauką). Toks kreipinys būdingas 1990 (7 pvz.) ir 2013 metų Seimui:

7) Ar komisija sutinka, kad dauguma balsavo už? (Vytautas Landsbergis balsų skaičiuotojui, $1990 \mathrm{~m}$. rugsèjo $4 \mathrm{~d}$., 1 posédis, rudens sesija). 
I Seimo narius taip ir kreipiamasi - Seimo nariai. Tiesiog kreipiamasi ị asmenis, dirbančius Seime, politikus. Kalbètojas dažniau ị juos kreipiasi netiesiogiai, jis vengia tiesiogiai Seimo narių kažko prašyti ar jiems siūlyti, tai galètų būti per daug tiesmuka, pasirenkama neutralesnè ir švelnesnè pozicija - kreipiamasi trečiojo asmens forma, bandoma tarsi netiesiogiai paveikti adresatus. Beje, toks kreipinys būdingas tik 2013 metų Seimui:

8) Prašyčiau Seimo narių bent metus neteikti pasiūlymų dèl šito klausimo, nes iš tikruju jis yra per daug jautrus (Eligijus Masiulis, 2013 m. liepos 2 d., 72 posédis, pavasario sesija).

1 lentele

\begin{tabular}{|c|c|c|c|c|c|c|c|c|c|c|c|}
\hline \multicolumn{12}{|c|}{ Daikt. ịvardijimas } \\
\hline \multicolumn{4}{|c|}{$1923 \mathrm{~m}}$. & \multicolumn{4}{|c|}{$1990 \mathrm{~m}$} & \multicolumn{4}{|c|}{$2013 \mathrm{~m}$. } \\
\hline \multicolumn{2}{|c|}{ Rudens s-ja } & \multicolumn{2}{|c|}{$\begin{array}{c}\text { Pavasario } \\
\text { s-ja }\end{array}$} & \multicolumn{2}{|c|}{ Rudens s-ja } & \multicolumn{2}{|c|}{$\begin{array}{c}\text { Pavasario } \\
\text { s-ja }\end{array}$} & \multicolumn{2}{|c|}{ Rudens s-ja } & \multicolumn{2}{|c|}{$\begin{array}{c}\text { Pavasario } \\
\text { s-ja }\end{array}$} \\
\hline $\begin{array}{c}\text { Ties. } \\
\text { kr. }\end{array}$ & $\begin{array}{c}\mathrm{Ne}- \\
\text { ties. } \\
\text { kr. }\end{array}$ & $\begin{array}{c}\text { Ties. } \\
\text { kr. }\end{array}$ & $\begin{array}{c}\mathrm{Ne}- \\
\text { ties. } \\
\text { kr. }\end{array}$ & $\begin{array}{c}\text { Ties. } \\
\text { kr. }\end{array}$ & $\begin{array}{c}\mathrm{Ne}- \\
\text { ties. } \\
\text { kr. }\end{array}$ & $\begin{array}{c}\text { Ties. } \\
\text { kr. }\end{array}$ & $\begin{array}{c}\mathrm{Ne}- \\
\text { ties. } \\
\mathrm{kr} .\end{array}$ & $\begin{array}{c}\text { Ties. } \\
\text { kr. }\end{array}$ & $\begin{array}{c}\mathrm{Ne}- \\
\text { ties. } \\
\mathrm{kr} .\end{array}$ & $\begin{array}{c}\text { Ties. } \\
\text { kr. }\end{array}$ & $\begin{array}{c}\mathrm{Ne}- \\
\text { ties. } \\
\mathrm{kr} .\end{array}$ \\
\hline $\mathbf{0}$ & 45 & 17 & 129 & 10 & 86 & 21 & 75 & 116 & 113 & 272 & 120 \\
\hline
\end{tabular}

\subsection{Kreipimasis būdvardiškuoju dalyviu / būdvardžiu + daikta-} vardžiu. Kartais prie daiktavardžio šliejamas būdvardiškasis dalyvis gerbiamasis / -ieji, todèl kreipinys atrodo itin oficialus, formalus ir pagarbus. Tokia kreipimosi konstrukcija būdvardiškasis dalyvis / būdvardis + daiktavardis kreiptasi tada, kai tiesiog norèta atkreipti politikų dèmesi prieš perduodant jiems naują informaciją, sakant sveikinimo kalbą. Šiuo atveju kreipinys buvo vartojamas visų trijų laikotarpių Seimuose. Kreipiniai labai neutralūs, išlaikomi oficialūs ir pagarbūs santykiai:

9) Pirm, negu pradèsime dirbti paprasta mūsų darbą, randu reikalinga pratarti i jus, gerbiamieji atstovai, bent kelis žodžius (posėdžio pirmininkas Justinas Staugaitis, 1923 m. rugsejo 18 d., 25 posedis, rudens sesija); 
10) Gerbiamieji deputatai, rengèju ir Ekonomikos ministerijos pasiūlymai išdèstyti popieriuje, projekte (posèdžio pirmininkas Aleksandras Abišala, $1990 \mathrm{~m}$. liepos 31 d., 121 posédis, pavasario sesija);

11) Gerbiamieji kolegos, mieli bičiuliai, noriu pasveikinti jus, šiandien jau antra diena, kai Lietuva pirmininkauja Europos Sajungos Tarybai (Vydas Gedvilas, 2013 m. liepos 2 d., 72 posédis, pavasario sesija).

Dažnai adresantai vietoj būdvardiškojo dalyvio gerbiamieji prieš daiktavardinị ịvardijimą pavartoja būdvardžius mielieji, malonūs. Tokiu būdu komunikacinè distancija tarp adresanto ir adresato sumažèja, jų tarpasmeninis santykis tampa artimesnis, rodos, ne toks oficialus. Šios kreipimosi konstrukcijos 1990 metais vartojamos tada, kai adresantas praneša pozityvią naujieną, kalba apie dalykus, kurie aktualūs tiek adresantui, tiek adresatui, taip adresantas tarsi parodo, kad adresatas jam yra artimas (12 pvz.). 2013 metais kreipinys mielieji kolegos vartojamas, kai kalbama apie kasdienius, buitinius dalykus, t. y. taip $\mathfrak{i}$ politikus Seimo Pirmininkas kreipiasi tol, kol aptariami su ịstatymų leidyba tiesiogiai nesusiję klausimai, - taip kreipiasi prieš darbo pradžią ir pabaigą (13 pvz.):

12) Malonūs kolegos, aš noriu pasidžiaugti, kad mūsų Aukščiausiojoje Taryboje lankosi garbingi svečiai. Jie dabar yra mūsu saleje (Vytautas Landsbergis, $1990 \mathrm{~m}$. rugsèjo $11 \mathrm{~d}$., 4 posédis, rudens sesija);

13) Mielieji kolegos, jeigu mes baigsime ir šiandien bus paskutinis mūsu posèdis šioje saleje, tai visus kviečiu pasiimti savo asmeninius daiktus, nes šioje saleje vyks parlamentinio matmens pirmininkaujant Europos Sajungos Tarybai renginiai (Vydas Gedvilas, 2013 m. liepos 2 d., 72 posedis, pavasario sesija).

Netiesiogiai 1990 metais adresantas ị adresatą kreipiasi, kai dẻl ko nors prieštarauja. Taip išlaikoma komunikacinè distancija:

14) Noréčiau priminti ir pabrěžti gerbiamiesiems kolegoms, kad truputi klystame ir painiojame funkcijas (Vidmantas Baldišis, $1990 \mathrm{~m}$. liepos 31 d., 121 posédis, pavasario sesija). 
2 lentelè

\begin{tabular}{|c|c|c|c|c|c|c|c|c|c|c|c|}
\hline \multicolumn{12}{|c|}{ Būdvard. dalyvis / būdvardis + daiktavardis } \\
\hline \multicolumn{4}{|c|}{$1923 \mathrm{~m}}$. & \multicolumn{4}{|c|}{$1990 \mathrm{~m}}$. & \multicolumn{4}{|c|}{$2013 \mathrm{~m}}$. \\
\hline \multicolumn{2}{|c|}{ Rudens s-ja } & \multicolumn{2}{|c|}{$\begin{array}{c}\text { Pavasario } \\
\text { s-ja }\end{array}$} & \multicolumn{2}{|c|}{ Rudens s-ja } & \multicolumn{2}{|c|}{$\begin{array}{c}\text { Pavasario } \\
\text { s-ja }\end{array}$} & \multicolumn{2}{|c|}{ Rudens s-ja } & \multicolumn{2}{|c|}{$\begin{array}{c}\text { Pavasario } \\
\text { s-ja }\end{array}$} \\
\hline $\begin{array}{c}\text { Ties. } \\
\text { kr. }\end{array}$ & $\begin{array}{c}\mathrm{Ne}- \\
\text { ties. } \\
\text { kr. }\end{array}$ & $\begin{array}{c}\text { Ties. } \\
\text { kr. }\end{array}$ & $\begin{array}{c}\mathrm{Ne}- \\
\text { ties. } \\
\text { kr. }\end{array}$ & $\begin{array}{c}\text { Ties. } \\
\text { kr. }\end{array}$ & $\begin{array}{c}\mathrm{Ne}- \\
\text { ties. } \\
\text { kr. }\end{array}$ & $\begin{array}{c}\text { Ties. } \\
\text { kr. }\end{array}$ & $\begin{array}{c}\mathrm{Ne}- \\
\text { ties. } \\
\mathrm{kr} .\end{array}$ & $\begin{array}{c}\text { Ties. } \\
\text { kr. }\end{array}$ & $\begin{array}{c}\mathrm{Ne}- \\
\text { ties. } \\
\text { kr. }\end{array}$ & $\begin{array}{c}\text { Ties. } \\
\text { kr. }\end{array}$ & $\begin{array}{l}\mathrm{Ne}- \\
\text { ties. } \\
\mathrm{kr} .\end{array}$ \\
\hline 6 & $\mathbf{0}$ & 43 & $\mathbf{0}$ & 571 & 78 & 586 & 59 & 481 & 14 & 717 & 20 \\
\hline
\end{tabular}

2. Kreipimasis vardu. 2013 metų pavasario ir rudens sesijų stenogramų duomenys rodo, jog politikai vieni $\mathfrak{i}$ kitus per Seimo posėdžius dažnai kreipèsi vardais. Paprastai, kai kreipiamasi vardu tiesiogiai, mandagiai arba draugiškai perduodama informacija, pasakoma kokia nors pastaba, tada nevengiama tiesioginio santykio su pašnekovu. Dažniausiai vardu kreipèsi Seimo Pirmininkas Vydas Gedvilas - tokị kreipimąsi lèmè ir amžiaus kriterijus - vardu jis kreipèsi ì gerokai jaunesnius už save politikus, pavyzdžiui, ’̇ Remigijų Žemaitaitị ir Jolitą Vaickienę, arba ị savo bendraamžius - Petrą Gražulị, Julių Sabatauską. Vardu Seimo Pirmininkas kreipèsi ir ị Seimo narius, kurie nedaug jaunesni arba vyresni už ji patị - Aureliją Stancikienę, Mečislovą Zasčiurinską ir Bronių Bradauską. Toks adresato ịvardijimas vartojamas, kai Seimo Pirmininkas kviečia Seimo narius kalbėti - perskaityti pranešimą, pasiūlymą ar užduoti klausimą, pavyzdžiui:

15) Remigijau, jūs pristatykite (posėdžio pirmininkas Vydas Gedvilas Remigijui Žemaitaičiui, 2013 m. birželio 13 d., 62 posédis, pavasario sesija).

Vardais kreipiamasi ir tada, kai situacija nèra formali, galbūt nèra susijusi su politika, tiesiog yra kreipiamasi dèl paprastų ir buitinių dalykų, pavyzdžiui:

16) Juliau, nejaugi toks neraštingas esi? Perskaityk, ir viskas, svarstome (Petras Gražulis Juliui Sabatauskui, 2013 m. birželio 13 d., 62 posèdis, pavasario sesija). 
Iš tiesų netiesioginiai kreipiniai nedaug kuo skiriasi nuo tiesioginių, tačiau įvardydamas savo adresatą netiesiogiai, adresantas tarsi leidžia pokalbyje dalyvauti ir kitiems klausytojams, informacija skiriama ir jiems, t. y. jiems pranešama, kieno eilè kalbèti, kam yra dékojama, kartais atrodo, jog Seimo Pirmininkas kreipdamasis tokiu kreipiniu, daro tai visų kitų esančių šalia politikų vardu. Netiesiogiai i kalbètoją kreiptasi, kai norèta pranešti politikui, kad atejjo jo eilè kalbèti (17 pvz.) arba kai norèta jam perduoti informaciją, pasakyti pastabą (18 pvz.):

17) Kitas klaus Kazimieras (posėdžio pirmininkas Vydas Gedvilas Kazimierui Kuzminskui, 2013 m. birželio 27 d., 70 posédis, pavasario sesija);

18) Gerbiamieji kolegos, norèčiau priminti Vytautui, kad buvo 800 Lt minimali alga, yra 1000 Lt (posédžio pirmininkas Vydas Gedvilas Vytautui Matulevičiui, 2013 m. rugsèjo 19 d., 80 posédis, rudens sesija).

3 lentelè

\begin{tabular}{|c|c|c|c|c|c|c|c|c|c|c|c|}
\hline \multicolumn{12}{|c|}{ Vardas } \\
\hline \multicolumn{4}{|c|}{$1923 \mathrm{~m}}$. & \multicolumn{4}{|c|}{$1990 \mathrm{~m}}$. & \multicolumn{4}{|c|}{$2013 \mathrm{~m}$. } \\
\hline \multicolumn{2}{|c|}{ Rudens s-ja } & \multicolumn{2}{|c|}{$\begin{array}{c}\text { Pavasario } \\
\text { s-ja }\end{array}$} & \multicolumn{2}{|c|}{ Rudens s-ja } & \multicolumn{2}{|c|}{$\begin{array}{c}\text { Pavasario } \\
\text { s-ja }\end{array}$} & \multicolumn{2}{|c|}{ Rudens s-ja } & \multicolumn{2}{|c|}{$\begin{array}{c}\text { Pavasario } \\
\text { s-ja }\end{array}$} \\
\hline $\begin{array}{c}\text { Ties. } \\
\text { kr. }\end{array}$ & $\begin{array}{c}\mathrm{Ne}- \\
\text { ties. } \\
\text { kr. }\end{array}$ & $\begin{array}{c}\text { Ties. } \\
\text { kr. }\end{array}$ & $\begin{array}{c}\mathrm{Ne}- \\
\text { ties. } \\
\mathrm{kr} .\end{array}$ & $\begin{array}{c}\text { Ties. } \\
\text { kr. }\end{array}$ & $\begin{array}{c}\mathrm{Ne}- \\
\text { ties. } \\
\text { kr. }\end{array}$ & $\begin{array}{c}\text { Ties. } \\
\text { kr. }\end{array}$ & $\begin{array}{c}\mathrm{Ne}- \\
\text { ties. } \\
\mathrm{kr} .\end{array}$ & $\begin{array}{c}\text { Ties. } \\
\text { kr. }\end{array}$ & $\begin{array}{c}\mathrm{Ne}- \\
\text { ties. } \\
\text { kr. }\end{array}$ & $\begin{array}{c}\text { Ties. } \\
\text { kr. }\end{array}$ & $\begin{array}{c}\mathrm{Ne}- \\
\text { ties. } \\
\mathrm{kr} .\end{array}$ \\
\hline 0 & 0 & 0 & $\mathbf{0}$ & 1 & 0 & 0 & 0 & 21 & 8 & 58 & 14 \\
\hline
\end{tabular}

2.1. Kreipimasis būdvardiškuoju dalyviu + vardu. Tokio kreipinio pagrindas - vardas ir prieš vardą pridedamas būdvardiškasis dalyvis. Dvinaris kreipinys ${ }^{13}$ padeda kurti norimus santykius tarp adresanto ir adresato, pavyzdžiui - oficialesnius arba asmeniškesnius, tai priklauso nuo to, koks būdvardis vartojamas prieš vardą.

${ }^{13}$ Bankauskaitè-Sereikienė, G., Mickienė, I., Šiaučiulytė, S. 2008. Balio Sruogos asmeninių laiškų kreipinių raiška. Respectus Philologicus. Nr. 13 (2008), p. 83. 
Per pavasario ir rudens sesijas 2013 metais sudètiniu kreipiniu $b \bar{u}$ dvardiškasis dalyvis + vardas asmuo kviečiamas kalbèti. Kreipiantis tiesiogiai, atrodo, kad užmezgamas draugiškas santykis su kitu asmeniu, tačiau būdvardinis dalyvis padeda palaikyti pagarbų atstumą, formalumą:

19) Gerbiamoji Zita, prašom, žodis suteikiamas jums (posédžio pirmininkas Vytautas Gapšys Zitai Žvikienei, 2013 m. liepos 2 d., 72 posédis, pavasario sesija).

Vardu asmuo yra išskiriamas iš kitų. Tokiu kreipiniu nevengiama kreiptis ị asmenị ir tada, kai jam pasakoma kritika, pastaba arba suteikiama ne itin maloni informacija. Būdvardiškasis dalyvis gerbiamasis eidamas sykiu su vardu kreipinị daro oficialesni, tada ir santykis tarp adresanto ir adresato atrodo oficialesnis, komunikacinè distancija tolimesnè, tačiau tokiame kontekste šis dalyvis skamba kiek ironiškai:

20) Gerbiamasis Andriau, jūs nebūkite gudresnis už visus (posėdžio pirmininkas Vytautas Gapšys Andriui Kubiliui, 2013 m. liepos 2 d., 72 posédis, pavasario sesija).

Ši kreipinio konstrukcija skamba itin mandagiai, kai politikai ką nors prašo atlikti kitų politikų (21 pvz.), tokiu atveju išlaikomas ir pagarbus atstumas, ir kartu draugiški ir dalykiški santykiai:

21) Tada, jeigu bus palaikymas, gerbiamasis Broniau, jūs paaiškinsite komiteto nuomonę. Gerai? (posėdžio pirmininkas Vytautas Gap̌̌ys Broniui Bradauskui, 2013 m. liepos 2 d., 72 posedis, pavasario sesija).

Mandagumas ir pagarba kreipinyje išlieka ir tada, kai kitam asmeniui pasakoma nepikta pastaba (22 pvz.):

22) Gerbiamasis Petrai, nesiginčykite, registruokite, niekas ne prieš, kad jūs teiktumète pasiūlymą, bet nustatyta tvarka (posèdžio pirmininkas Vytautas Gap̌̌ys Petrui Gražuliui, 2013 m. birželio 27 d., 70 posédis, pavasario sesija).

Seimo nariai vieni ị kitus kreipiasi trečiojo asmens forma - i pokalbị, dialogą įtraukiami ir kiti politikai, tarsi informacija, sakoma asmeniui, ì kurị yra kreipiamasi, liečia ir kitus politikus. Tokiu būdu kreipiamasi, kai norima suteikti informacijos, atkreipti kito asmens dėmesį (23 pvz.): 
23) Aš noriu atkreipti gerbiamojo Broniaus demesi, kad čia kalbama apie datas (posedžio pirmininkas Vydas Gedvilas Broniui Bradauskui, $2013 \mathrm{~m}$. rugsèjo 19 d., 80 posédis, rudens sesija).

4 lentelè

\begin{tabular}{|c|c|c|c|c|c|c|c|c|c|c|c|}
\hline \multicolumn{12}{|c|}{ Būdvard. dalyvis + vardas } \\
\hline \multicolumn{4}{|c|}{$1923 \mathrm{~m}}$. & \multicolumn{4}{|c|}{$1990 \mathrm{~m}}$. & \multicolumn{4}{|c|}{$2013 \mathrm{~m}$. } \\
\hline \multicolumn{2}{|c|}{ Rudens s-ja } & \multicolumn{2}{|c|}{$\begin{array}{c}\text { Pavasario } \\
\text { s-ja }\end{array}$} & \multicolumn{2}{|c|}{ Rudens s-ja } & \multicolumn{2}{|c|}{$\begin{array}{c}\text { Pavasario } \\
\text { s-ja }\end{array}$} & \multicolumn{2}{|c|}{ Rudens s-ja } & \multicolumn{2}{|c|}{$\begin{array}{c}\text { Pavasario } \\
\text { s-ja }\end{array}$} \\
\hline $\begin{array}{c}\text { Ties. } \\
\text { kr. }\end{array}$ & $\begin{array}{l}\mathrm{Ne}- \\
\text { ties. } \\
\text { kr. }\end{array}$ & $\begin{array}{c}\text { Ties. } \\
\text { kr. }\end{array}$ & $\begin{array}{c}\mathrm{Ne}- \\
\text { ties. } \\
\text { kr. }\end{array}$ & $\begin{array}{c}\text { Ties. } \\
\text { kr. }\end{array}$ & $\begin{array}{c}\mathrm{Ne}- \\
\text { ties. } \\
\text { kr. }\end{array}$ & $\begin{array}{c}\text { Ties. } \\
\text { kr. }\end{array}$ & $\begin{array}{c}\mathrm{Ne}- \\
\text { ties. } \\
\mathrm{kr} .\end{array}$ & $\begin{array}{c}\text { Ties. } \\
\text { kr. }\end{array}$ & $\begin{array}{c}\mathrm{Ne}- \\
\text { ties. } \\
\mathrm{kr} \text {. }\end{array}$ & $\begin{array}{c}\text { Ties. } \\
\text { kr. }\end{array}$ & $\begin{array}{c}\mathrm{Ne}- \\
\text { ties. } \\
\mathrm{kr} .\end{array}$ \\
\hline $\mathbf{0}$ & $\mathbf{0}$ & $\mathbf{0}$ & $\mathbf{0}$ & $\mathbf{0}$ & $\mathbf{0}$ & $\mathbf{0}$ & $\mathbf{0}$ & 32 & 3 & 68 & 4 \\
\hline
\end{tabular}

3. Kreipimasis būdvardiškuoju dalyviu / ịvardžiuotiniu būdvardžiu. Būdvardiškasis dalyvis eidamas kreipiniu dažnai atlieka daiktavardžio funkciją, tačiau labiau apibūdina tą, ị kurị yra kreipiamasi. Šis kreipinys tarsi rodo pagarbą adresatui, juk yra šaknis gerb-, vis dèlto tai tiesiog kreipinys, kuri patogu vartoti, kai reikia kreiptis i gana neapibrèžtą auditoriją arba ị asmeni, norint palaikyti kuo neutralesnius santykius. Toks adresato įvardijimas gali būti vartojamas ir vietoj daiktavardžių, pvz., politikai, Seimo nariai.

Šiuo kreipiniu kreipiamasi prieš perduodant politikams kokią nors informaciją. Toks kreipinys ypač neutralus ir oficialus:

24) Gerbiamieji! Kadangi mišku yra taip opus klausimas ir mes tiek galime suprasti, kad miškas tai Lietuvos pamatas <...> (Nikodemas Radis, 1923 m. liepos 13 d., 14 posédis, pavasario sesija);

25) Gerbiamieji, kada buvo svarstoma, kiek nariu turi turèti partija, kad ji galètu būti îregistruota kaip partija, tai buvo manoma ir apie tai; tiesiog tai yra koncepcija, kokiu partiju Lietuvoje reikia (Liudvikas Narcizas Rasimavičius, $1990 \mathrm{~m}$. rugsejo 21 d., 12 posédis, rudens sesija);

26) Gerbiamieji, man tenka didele garbe pradèti ši iškilminga posédi (posėdžio pirmininkas Vydas Gedvilas, 2013 m. liepos 4 d., 74 posédis, pavasario sesija). 
Ivardžiuotiniais būdvardžiais brangieji ir mielieji kreipiamasi siekiant labiau atkreipti auditorijos dėmesį, apeliuoti i ją, taip stengiamasi užmegzti artimesnị santykį, adresantas nori parodyti, jog iškilusi problema ar klausimas ji patị ir jo adresatus suartina, tai tampa bendra problema (27 pvz.). Taip kreipiamasi, kai perduodama ir teigiamo turinio informacija (28 pvz.). Beje, toks įvardžiuotinių dalyvių vartojimas būdingas tik 2013 metų Seimui:

27) Ačiū. Aš noriu pasakyti, brangieji, kaip ir Šilumos jstatymo atveju, kur mes skubame su visais šiais įstatymais? (Dainius Kreivys, 2013 m. liepos 2 d., 72 posédis, pavasario sesija);

28) Mielieji, aš kviečiu visus dar sykị pažiūrèti, ka rodè žiniasklaida. Žiniasklaida nerode ir negalejo rodyti, kaip vartojamas alkoholis. <...> Jokio lébavimo, alkoholio upiu ar delikatesų kalnu, apie kuriuos kalbejjo už kadro vedantieji, nebuvo. Iš tiesu po oficialios dalies 17.30 val. prasidejo kultūrinè programa. Po kultūrinès programos, taip, žmonès laisvu laiku už savo pinigus, noriu pabrèžti, nè vienas alkoholio lašas nebuvo pirktas iš pinigu, apie kuriuos aš anksčiau minejjau, tai buvo visu surinkti, sudèti pinigai, susèdo, pabendravo, beje, labai kultūringai. Aš asmeniškai išvažiavau apie 21 val. (Valentinas Mazuronis, 2013 m. spalio 1 d., 82 posédis, rudens sesija).

5 lentelè

\begin{tabular}{|c|c|c|c|c|c|c|c|c|c|c|c|}
\hline \multicolumn{12}{|c|}{ Būdvard. dalyvis / įvardž. būdvardis } \\
\hline \multicolumn{4}{|c|}{$1923 \mathrm{~m}}$. & \multicolumn{4}{|c|}{$1990 \mathrm{~m}}$. & \multicolumn{4}{|c|}{$2013 \mathrm{~m}}$. \\
\hline \multicolumn{2}{|c|}{ Rudens s-ja } & \multicolumn{2}{|c|}{$\begin{array}{c}\text { Pavasario } \\
s-j a\end{array}$} & \multicolumn{2}{|c|}{ Rudens s-ja } & \multicolumn{2}{|c|}{$\begin{array}{c}\text { Pavasario } \\
\text { s-ja }\end{array}$} & \multicolumn{2}{|c|}{ Rudens s-ja } & \multicolumn{2}{|c|}{$\begin{array}{c}\text { Pavasario } \\
s-j a\end{array}$} \\
\hline $\begin{array}{c}\text { Ties. } \\
\text { kr. }\end{array}$ & $\begin{array}{c}\mathrm{Ne}- \\
\text { ties. } \\
\text { kr. }\end{array}$ & $\begin{array}{c}\text { Ties. } \\
\text { kr. }\end{array}$ & $\begin{array}{c}\mathrm{Ne}- \\
\text { ties. } \\
\mathrm{kr} .\end{array}$ & $\begin{array}{c}\text { Ties. } \\
\text { kr. }\end{array}$ & $\begin{array}{c}\mathrm{Ne}- \\
\text { ties. } \\
\text { kr. }\end{array}$ & $\begin{array}{c}\text { Ties. } \\
\text { kr. }\end{array}$ & $\begin{array}{c}\mathrm{Ne}- \\
\text { ties. } \\
\mathrm{kr} .\end{array}$ & $\begin{array}{c}\text { Ties. } \\
\text { kr. }\end{array}$ & $\begin{array}{c}\mathrm{Ne}- \\
\text { ties. } \\
\text { kr. }\end{array}$ & $\begin{array}{c}\text { Ties. } \\
\text { kr. }\end{array}$ & $\begin{array}{c}\mathrm{Ne}- \\
\text { ties. } \\
\text { kr. }\end{array}$ \\
\hline 6 & 0 & 69 & 0 & 15 & $\mathbf{0}$ & 21 & $\mathbf{0}$ & 11 & $\mathbf{0}$ & 28 & $\mathbf{0}$ \\
\hline
\end{tabular}

4. Kreipimasis daiktavardiniu kreipiniu + pavarde. Šio kreipinio pagrindas - pavardè, daiktavardžiu minimos asmens tuo metu Seime einamos pareigos arba pagarbus kreipinys pone, būdingas ne- 
priklausomybès laikų tradicijai ${ }^{14}$. Taip ì politiką kreiptasi tada, kai jis kviečiamas kalbèti - duoti priesaikos arba skaityti savo pranešimą. Kreipiamasi netiesiogiai, nes informacija skirta ne tik pačiam adresatui, ji skirta ir posédyje dalyvaujantiems politikams - tiesiog pranešama, kas turi ateiti ir kalbèti (29 pvz.). Neretai šis netiesioginis kreipinys vartojamas, kai kalbėtojas tiesiog vengia asmeniško ir tiesioginio santykio su savo adresatu, nes dẻl ko nors prieštarauja, t. y. nesutinka su juo, pataiso ji, suteikia naujos informacijos - sako tai, kas adresatui gali atrodyti gana neigiamai, kaip puolimas, taip pat vengiama tiesioginio santykio ir tada, kai kalbètojas aštriai kritikuoja kitą politiką (30 pvz.).

29) Prašau atstova Kasaiti duoti priesaikg ir iškilminga pasižadèjima (posėdžio pirmininkas Justinas Staugaitis, 1923 m. liepos 6 d., 7 posèdis, pavasario sesija);

30) Ir labai klysta atstovas Plečkaitis, jeigu jis sako, kad esa pas mus tokiu ükiu, kur jau dirbama 8 valandos ir kad tie ükiai puikiausiai stovị. Jei reikètu dirbti 8 valandas, kaip čia įstatyme pažymèta, tad šiais metais būtume pasilikę be duonos ir atstovas Plečkaitis nebūtu turèjęs ka valgyti (Petras Josiukas, 1923 m. rugsèjo 18 d., 25 posédis, rudens sesija).

6 lentelè

\begin{tabular}{|c|c|c|c|c|c|c|c|c|c|c|c|}
\hline \multicolumn{12}{|c|}{ Daikt. kreipinys + pavardè } \\
\hline \multicolumn{4}{|c|}{$1923 \mathrm{~m}}$. & \multicolumn{4}{|c|}{$1990 \mathrm{~m}}$. & \multicolumn{4}{|c|}{$2013 \mathrm{~m}$. } \\
\hline \multicolumn{2}{|c|}{ Rudens s-ja } & \multicolumn{2}{|c|}{$\begin{array}{c}\text { Pavasario } \\
\text { s-ja }\end{array}$} & \multicolumn{2}{|c|}{ Rudens s-ja } & \multicolumn{2}{|c|}{$\begin{array}{c}\text { Pavasario } \\
\text { s-ja }\end{array}$} & \multicolumn{2}{|c|}{ Rudens s-ja } & \multicolumn{2}{|c|}{$\begin{array}{c}\text { Pavasario } \\
\text { s-ja }\end{array}$} \\
\hline $\begin{array}{c}\text { Ties. } \\
\text { kr. }\end{array}$ & $\begin{array}{c}\mathrm{Ne}- \\
\text { ties. } \\
\text { kr. }\end{array}$ & $\begin{array}{c}\text { Ties. } \\
\text { kr. }\end{array}$ & $\begin{array}{c}\mathrm{Ne}- \\
\text { ties. } \\
\mathrm{kr} .\end{array}$ & $\begin{array}{c}\text { Ties. } \\
\text { kr. }\end{array}$ & $\begin{array}{c}\mathrm{Ne}- \\
\text { ties. } \\
\mathrm{kr} .\end{array}$ & $\begin{array}{c}\text { Ties. } \\
\text { kr. }\end{array}$ & $\begin{array}{c}\mathrm{Ne}- \\
\text { ties. } \\
\mathrm{kr} .\end{array}$ & $\begin{array}{c}\text { Ties. } \\
\text { kr. }\end{array}$ & $\begin{array}{c}\mathrm{Ne}- \\
\text { ties. } \\
\text { kr. }\end{array}$ & $\begin{array}{c}\text { Ties. } \\
\text { kr. }\end{array}$ & $\begin{array}{c}\mathrm{Ne}- \\
\text { ties. } \\
\text { kr. }\end{array}$ \\
\hline $\mathbf{0}$ & 73 & 3 & 79 & $\mathbf{0}$ & $\mathbf{0}$ & $\mathbf{0}$ & $\mathbf{0}$ & $\mathbf{0}$ & $\mathbf{0}$ & $\mathbf{0}$ & $\mathbf{0}$ \\
\hline
\end{tabular}

${ }_{14}$ Čepaitienè, G. Lietuviu kalbos etiketas: semantika ir pragmatika. Šiauliai: Šiaulių universiteto leidykla, 2007, p. 85. 
4.1. Kreipimasis vardu + pavarde. Kreipinys - vardas + pavarde atrodo vienas iš neutraliausių, tiesiog šiuo kreipiniu asmuo yra išskiriamas iš kitų, rodos, kreipdamasis šiuo kreipiniu adresantas neatskleidžia subjektyvaus požiūrio ị adresatą. Per 1923 metų Seimo posėdžius politikai vieni $\mathfrak{i}$ kitus beveik nesikreipe vardu ir pavarde, buvo tik 8 kartus kreiptasi ị Seimo narị Tadą Aleliūną netiesiogiai, kreipèsi Seimo narys Jeronimas Plečkaitis. Tokiu būdu parlamentaras ị kolegą kreipėsi išreikšdamas kritiškas pastabas:

31) Bet aš manau, jog Tadas Aleliūnas nepasakys, kad žvalgyba reikètu panaikinti: jis pasakys, jog žvalgybos jokiu būdu negalima naikinti. Kaip tik sakoma, gerbiamieji, kad mūsu valdininkai yra netikę ir mes labai daug turime įrodymu, kur mūsu valdininkai visai netikusiai elgiasi (Jeronimas Plečkaitis Tadui Aleliūnui, 1923 m. liepos 19 d., 18 posédis, pavasario sesija).

1990 metų pavasario sesijos Seimo posėdžiuose Seimo nariai 8 kartus kreipèsi vardu ir pavarde vieni ị kitus, tačiau kreipiniai buvo netiesioginiai, paprastai Seimo Pirmininkas taip kreipdavosi kviesdamas kalbèti, pavyzdžiui:

32) Prašau Nagli Puteiki ị tribūną plačiau pristatyti šio įstatymo projektą (Aleksandras Abišala, 1990 m. liepos 19 d., 18 posédis, pavasario sesija).

Stenogramose, kai kreipiamasi vardu ir pavarde $\mathfrak{i}$ asmeni posédžiuose, ne visada parašomas visas vardas prieš pavardę, dažniausiai parašoma tik pirma vardo raide - taip tiesiog yra patogiau ir greičiau užrašyti vardą, negu nuolat jị užrašinèti - juk taip kreipiamasi itin dažnai. Seimo nariai taip ne tik kviečiami kalbèti, tokiu būdu pasakoma kitiems Seimo nariams, kas ateis sakyti savo kalbos.

2013 metais pavasario ir rudens sesijų metu pirmininkas ị Seimo narius vardu ir pavarde kreipèsi tada, kai kvietė juos kalbèti - perskaityti savo pranešimą ar pasiūlymą dèl įstatymo, pavyzdžiui:

33) Nuomone prieš - K. Masiulis (Vydas Gapšys, 2013 m. rugsèjo 10 d., 75 posédis, rudens sesija). 
Tai ịprastas kreipimosi būdas 2013 metais, kai reikia pakviesti politiką kalbèti Seimo posèdžiuose. Toks kreipinys skamba formaliai, tokiu būdu nesiekiama kaip nors kreiptis ị kitą asmenị, labiau siekiama pranešti auditorijai, kuris iš Seimo narių skaitys pranešimą. Kreipinio funkciją šis kreipinys atlieka tik tiek, kiek juo adresatui pasakoma, kad atèjo jo eilè kalbèti.

7 lentelè

\begin{tabular}{|c|c|c|c|c|c|c|c|c|c|c|c|}
\hline \multicolumn{12}{|c|}{ Vardas + pavardè } \\
\hline \multicolumn{4}{|c|}{$1923 \mathrm{~m}}$. & \multicolumn{4}{|c|}{$1990 \mathrm{~m}}$. & \multicolumn{4}{|c|}{$2013 \mathrm{~m}$. } \\
\hline \multicolumn{2}{|c|}{ Rudens s-ja } & \multicolumn{2}{|c|}{$\begin{array}{c}\text { Pavasario } \\
\text { s-ja }\end{array}$} & \multicolumn{2}{|c|}{ Rudens s-ja } & \multicolumn{2}{|c|}{$\begin{array}{c}\text { Pavasario } \\
\text { s-ja }\end{array}$} & \multicolumn{2}{|c|}{ Rudens s-ja } & \multicolumn{2}{|c|}{$\begin{array}{c}\text { Pavasario } \\
\text { s-ja }\end{array}$} \\
\hline $\begin{array}{c}\text { Ties. } \\
\text { kr. }\end{array}$ & $\begin{array}{c}\mathrm{Ne}- \\
\text { ties. } \\
\text { kr. }\end{array}$ & $\begin{array}{c}\text { Ties. } \\
\text { kr. }\end{array}$ & $\begin{array}{c}\mathrm{Ne}- \\
\text { ties. } \\
\text { kr. }\end{array}$ & $\begin{array}{c}\text { Ties. } \\
\text { kr. }\end{array}$ & $\begin{array}{l}\mathrm{Ne}- \\
\text { ties. } \\
\text { kr. }\end{array}$ & $\begin{array}{c}\text { Ties. } \\
\text { kr. }\end{array}$ & $\begin{array}{c}\mathrm{Ne}- \\
\text { ties. } \\
\mathrm{kr} .\end{array}$ & $\begin{array}{c}\text { Ties. } \\
\text { kr. }\end{array}$ & $\begin{array}{c}\mathrm{Ne}- \\
\text { ties. } \\
\mathrm{kr} \text {. }\end{array}$ & $\begin{array}{c}\text { Ties. } \\
\text { kr. }\end{array}$ & $\begin{array}{c}\mathrm{Ne}- \\
\text { ties. } \\
\text { kr. }\end{array}$ \\
\hline $\mathbf{0}$ & 8 & $\mathbf{0}$ & $\mathbf{0}$ & $\mathbf{0}$ & 3 & $\mathbf{0}$ & 8 & $\mathbf{0}$ & 100 & 1 & 224 \\
\hline
\end{tabular}

\subsection{Kreipimasis daiktavardiniu ịvardijimu + vardu + pavarde.} Kartais Seimo nariai vieni ị kitus kreipiasi ne tik vardu ir pavarde, dažnai prieš vardą ir pavardę jie prideda Seime einamų pareigų pavadinimus arba mandagius, pagarbius kreipinius, pavyzdžiui, pone. Toks kreipinys yra neutralus, labai formalus, ji vartojant siekiama išlaikyti gan tolimą distanciją su adresatu.

1990 metais per pavasario ir rudens sesijas tokiu kreipiniu politikai yra kviečiami kalbèti - tiesiog pasakoma, jog atėjo jų eilè kalbèti, tokiu būdu posėdžio pirmininkas praneša ir kitiems esantiems Seimo salèje, jog ateina skaityti savo kalbos kuris nors iš politikų (34 pvz.). Kreipinyje pasakomos asmens pareigos, vardas ir pavardè:

34) Deputatas V. Čepaitis (Aleksandras Abišala, 1990 m. rugsejjo $4 d$., 1 posédis, rudens sesija);

Netiesiogiai daiktavardiniu ịvardijimu, vardu ir pavarde kreipiamasi, kai Seimo nario norima ko nors paprašyti (35 pvz.), pasakyti 
nedidelę pastabą (36 pvz.). Išlaikoma pagarbi ir oficiali distancija tarp kalbančiojo ir jo adresato:

35) Ar deputatas Č. Juršénas galètu savo pasakyma išversti i valstybinę kalbą? (Aleksandras Abišala, 1990 m. rugsèjo 5 d., 3 posédis, rudens sesija);

36) Čia turbūt deputatas V. P. Plečkaitis truputi suklydo, šnekèdamas apie Prezidiumo Pirmininka (Jonas Tamulis, 1990 m. liepos 11 d., 103 posedis, pavasario sesija).

Kreipiantis i politiką tiesiogiai daiktavardiniu įvardijimu, vardu ir pavarde taip pat išlaikomas oficialus atstumas, tačiau santykis tarp adresanto ir adresato yra tiesioginis, taip kreipiamasi norint paklausti (37 pvz.), pasakyti naują informaciją arba pateikti pastabą (38 pvz.):

37) Deputate V. Žiemeli, norite paklausti? (Aleksandras Abišala, 1990 m. liepos 11 d., 103 posédis, pavasario sesija);

38) Deputate V. Beriozovai, pirmininkaujantis norètu, kad jūs diskusijoje dalyvautumète bendra tvarka, tai yra užsirašęs (Aleksandras Abišala, 1990 m. rugsèjo 11 d., 4 posèdis, rudens sesija).

Netiesioginiu daiktavardiniu ịvardijimu 2013 metais paprastai nurodomos politiko pareigos, einamos kitoje institucijoje (dažniausia tai būna asmuo, atvykęs su kokiais nors reikalais ị Lietuvos Seimą) arba Seime:

39) Pasidalinti mintimis kviečiu Seimo Pirmininko pavaduotoja J. Narkevičiu (posèdžio pirmininkas Vydas Gedvilas, 2013 m. rugsèjo 10 d., 75 posédis, rudens sesija).

Kartais ị kolegas kreipiamasi pagarbiu žodžiu ponas prieš vardą ir pavardę. Tada jiems yra suteikiama nauja informacija, norima jų ko nors paklausti:

40) Aš noréčiau ponui D. Kreiviui pasakyti, kad šiuo metu Vyriausybès kabinetas yra atlikęs labai išsamia analizę (Algirdas Butkevičius, 2013 m. liepos 2 d., 72 posédis, pavasario sesija). 
8 lentele

\begin{tabular}{|c|c|c|c|c|c|c|c|c|c|c|c|}
\hline \multicolumn{12}{|c|}{ Daikt. ịvardijimas + vardas + pavardè } \\
\hline \multicolumn{4}{|c|}{$1923 \mathrm{~m}}$. & \multicolumn{4}{|c|}{$1990 \mathrm{~m}}$. & \multicolumn{4}{|c|}{$2013 \mathrm{~m}$. } \\
\hline \multicolumn{2}{|c|}{ Rudens s-ja } & \multicolumn{2}{|c|}{$\begin{array}{c}\text { Pavasario } \\
\text { s-ja }\end{array}$} & \multicolumn{2}{|c|}{ Rudens s-ja } & \multicolumn{2}{|c|}{$\begin{array}{c}\text { Pavasario } \\
\text { s-ja }\end{array}$} & \multicolumn{2}{|c|}{ Rudens s-ja } & \multicolumn{2}{|c|}{$\begin{array}{c}\text { Pavasario } \\
\text { s-ja }\end{array}$} \\
\hline $\begin{array}{c}\text { Ties. } \\
\text { kr. }\end{array}$ & $\begin{array}{c}\mathrm{Ne}- \\
\text { ties. } \\
\mathrm{kr} .\end{array}$ & $\begin{array}{c}\text { Ties. } \\
\text { kr. }\end{array}$ & $\begin{array}{c}\mathrm{Ne}- \\
\text { ties. } \\
\mathrm{kr} .\end{array}$ & $\begin{array}{c}\text { Ties. } \\
\text { kr. }\end{array}$ & $\begin{array}{c}\mathrm{Ne}- \\
\text { ties. } \\
\text { kr. }\end{array}$ & $\begin{array}{c}\text { Ties. } \\
\text { kr. }\end{array}$ & $\begin{array}{c}\mathrm{Ne}- \\
\text { ties. } \\
\mathrm{kr} .\end{array}$ & $\begin{array}{c}\text { Ties. } \\
\text { kr. }\end{array}$ & $\begin{array}{c}\mathrm{Ne}- \\
\text { ties. } \\
\text { kr. }\end{array}$ & $\begin{array}{c}\text { Ties. } \\
\text { kr. }\end{array}$ & $\begin{array}{c}\mathrm{Ne}- \\
\text { ties. } \\
\text { kr. }\end{array}$ \\
\hline $\mathbf{0}$ & $\mathbf{0}$ & $\mathbf{0}$ & $\mathbf{0}$ & 1 & 29 & 5 & 31 & $\mathbf{0}$ & 35 & 2 & 76 \\
\hline
\end{tabular}

4.3. Kreipimasis būdvardiškuoju dalyviu + daiktavardiniu ịvardijimu + pavarde. Pereinamuoju laikotarpiu - iš tarybinio ị nepriklausomą - dažnai sakytinejje viešojoje kalboje buvo vartojami itin formalūs kreipiniai, pavyzdžiui, gerbiamas / ponas ir pan. + vardas ir vardas / gerbiamas / draugas / ponas / pareigos + pavardè / pareigos ${ }^{15}$. Tiriamame parlamentiniame diskurse ši forma dažniausiai būdinga kreipiniui gerbiamasis + adresato einamu pareigu pavadinimas Seime + adresato pavarde.

1990 metais šia konstrukcija politikai kreipèsi prieš perduodami vieni kitiems informaciją, kaip jau buvo minèta, taip paprastai kreipèsi Seimo Pirmininkas:

41) Gerbiamasis deputate Juknevičiau, salejje buvo apie 30 deputatu, ne vienas iš tu deputaty klausti nenorëjo (Aleksandras Abišala, 1990 m. rugsejo 4 d., 1 posédis, rudens sesija).

Kreipinys vartotas prieš perduodant neigiamo turinio informaciją, pavyzdžiui, pasakyta ne itin maloni pastaba:

42) Gerbiamasis deputate Ramonai, aš taip pat esu nusiteikęs taikingai. Galejote pastebèti, kad nè karto dar šiandien nesu pakèlęs balso (Aleksandras Abišala, 1990 m. rugsèjo 11 d., 4 posédis, rudens sesija).

${ }^{15}$ Girčienè, J. Adresato ịvardijimo raida. Žmogus kalbos erdvèje. 2011, Nr. 6, p. 1. 
9 lentelè

\begin{tabular}{|c|c|c|c|c|c|c|c|c|c|c|c|}
\hline \multicolumn{12}{|c|}{ Būdvard. dalyvis + daikt. ịvardijimas + pavardè } \\
\hline \multicolumn{4}{|c|}{$1923 \mathrm{~m}}$. & \multicolumn{4}{|c|}{$1990 \mathrm{~m}}$. & \multicolumn{4}{|c|}{$2013 \mathrm{~m}}$. \\
\hline \multicolumn{2}{|c|}{ Rudens s-ja } & \multicolumn{2}{|c|}{$\begin{array}{c}\text { Pavasario } \\
s-j a\end{array}$} & \multicolumn{2}{|c|}{ Rudens s-ja } & \multicolumn{2}{|c|}{$\begin{array}{c}\text { Pavasario } \\
\text { s-ja }\end{array}$} & \multicolumn{2}{|c|}{ Rudens s-ja } & \multicolumn{2}{|c|}{$\begin{array}{c}\text { Pavasario } \\
\text { s-ja }\end{array}$} \\
\hline $\begin{array}{c}\text { Ties. } \\
\text { kr. }\end{array}$ & $\begin{array}{c}\mathrm{Ne}- \\
\text { ties. } \\
\text { kr. }\end{array}$ & $\begin{array}{c}\text { Ties. } \\
\text { kr. }\end{array}$ & $\begin{array}{c}\mathrm{Ne}- \\
\text { ties. } \\
\text { kr. }\end{array}$ & $\begin{array}{c}\text { Ties. } \\
\text { kr. }\end{array}$ & $\begin{array}{c}\mathrm{Ne}- \\
\text { ties. } \\
\text { kr. }\end{array}$ & $\begin{array}{c}\text { Ties. } \\
\text { kr. }\end{array}$ & $\begin{array}{c}\mathrm{Ne}- \\
\text { ties. } \\
\mathrm{kr} .\end{array}$ & $\begin{array}{c}\text { Ties. } \\
\text { kr. }\end{array}$ & $\begin{array}{c}\mathrm{Ne}- \\
\text { ties. } \\
\text { kr. }\end{array}$ & $\begin{array}{c}\text { Ties. } \\
\text { kr. }\end{array}$ & $\begin{array}{c}\mathrm{Ne}- \\
\text { ties. } \\
\text { kr. }\end{array}$ \\
\hline $\mathbf{0}$ & $\mathbf{0}$ & $\mathbf{0}$ & 0 & 82 & $\mathbf{0}$ & $\mathbf{0}$ & $\mathbf{0}$ & 1 & $\mathbf{0}$ & $\mathbf{0}$ & $\mathbf{0}$ \\
\hline
\end{tabular}

4.4. Kreipimasis būdvardiškuoju dalyviu + vardu + pavarde. Kreipinio konstrukcijos formoje būdvardiškasis dalyvis + vardas $+p a-$ vardè dalyviu dažniausiai eina žodis gerbiamasis / -oji, kreipinys yra labai formalus ir oficialus, ịprastas mandagiai kreipiantis ị adresatą 1990 metais perduodant informaciją (43 pvz.), sakant kritišką pastabą (44 pvz.). Toks kreipinys vartojamas įvairiose situacijose, nes skamba labai formaliai ir neutraliai, padeda išlaikyti atstumą tarp situacijos dalyvių. Kreiptasi netiesiogiai:

43) Aš gerbiamajam Sauliui Šalteniui: be jokios abejonès, bus parašyta moldavu kalba (Emanuelis Zingeris, 1990 m. rugsejjo 5 d., 3 posédis, rudens sesija);

44) Aš matau, kad gerbiamasis J. Pangonis visiškai nežino, kaip šitas įstatymas buvo rengiamas (Saulius Pečeliūnas, 1990 m. rugsèjo 21 d., 12 posedis, rudens sesija).

Šiuo kreipiniu netiesiogiai 2013 metais kreipiamasi kviečiant Seimo narị kalbèti (45 pvz.). Taip pat kreipiamasi prieš išsakant nemalonią informaciją, pastabą, pateikiant nemalonų klausimą (46 pvz.). Kreipiamasi netiesiogiai, nes kalbama dažniausiai apie nemalonius dalykus, vengiama tiesmukumo, stengiamasi išlaikyti atstumą su adresatu:

45) Gerbiamasis A. Sysas. Prašom (Vydas Gedvilas, 2013 m. birželio 13 d., 62 posédis, pavasario sesija); 
46) Tačiau negaliu suprasti, kodèl gerbiamasis A. Matulas, būdamas medikas, visa laika viešai kalbėdamas apie tai, kad reikia nustoti girdyti jaunimą, kad iš tikrujų reikia kurti alkoholio vartojimo tradicijas, nepritarè mano pasiūlymui visiems tiems gèrimams, kaip aš minejjau, cheminiais preparatais praskiestiems alkoholio produktams, pasleptiems po fermentuoto gèrimo sidras pavadinimu... (Zita Žvikiené, $2013 \mathrm{~m}$. liepos 2 d., 72 posédis, pavasario sesija).

Kartais adresatas įvardijamas tiesioginiu kreipiniu - tada asmeniui yra išsakoma nemaloni informacija, kritika (47 pvz.). Kuriamas tarsi kiek asmeniškesnis santykis, tačiau pats kreipinys yra labai formalus ir oficialus, taigi vis tiek išlaikomas atstumas. Linkstama kreiptis tiesiogiai ir tada, kai kalbama apie pozityvius dalykus, pavyzdžiui, asmeniui, i kurị yra kreipiamasi, dèkojama (48 pvz.):

47) Aš galiu pasakyti, kad jūsų kai kurie, gerbiamasis Andriau Kubiliau, žmonès tikrai darè teisèsaugos institucijoms kai kuriuos spaudimus (Algirdas Butkevičius, 2013 m. birželio 13 d., 62 posèdis, pavasario sesija);

48) Gerbiamasis Vyteni Andriukaiti, aš tikrai labai nuoširdžiai dèkoju už knyga, kuria jūs man ịteikète, ir aš tikrai ja perskaitysiu laisvu nuo darbo metu (Eligijus Masiulis, 2013 m. birželio 25 d., 68 posèdis, pavasario sesija).

10 lentele

\begin{tabular}{|c|c|c|c|c|c|c|c|c|c|c|c|}
\hline \multicolumn{12}{|c|}{ Būdvard. dalyvis + vardas + pavardè } \\
\hline \multicolumn{4}{|c|}{$1923 \mathrm{~m}}$. & \multicolumn{4}{|c|}{$1990 \mathrm{~m}$} & \multicolumn{4}{|c|}{$2013 \mathrm{~m}$. } \\
\hline \multicolumn{2}{|c|}{ Rudens s-ja } & \multicolumn{2}{|c|}{$\begin{array}{c}\text { Pavasario } \\
\text { s-ja }\end{array}$} & \multicolumn{2}{|c|}{ Rudens s-ja } & \multicolumn{2}{|c|}{$\begin{array}{c}\text { Pavasario } \\
\text { s-ja }\end{array}$} & \multicolumn{2}{|c|}{ Rudens s-ja } & \multicolumn{2}{|c|}{$\begin{array}{c}\text { Pavasario } \\
\text { s-ja }\end{array}$} \\
\hline $\begin{array}{c}\text { Ties. } \\
\text { kr. }\end{array}$ & $\begin{array}{c}\mathrm{Ne}- \\
\text { ties. } \\
\mathrm{kr} .\end{array}$ & $\begin{array}{c}\text { Ties. } \\
\text { kr. }\end{array}$ & $\begin{array}{c}\mathrm{Ne}- \\
\text { ties. } \\
\mathrm{kr} .\end{array}$ & $\begin{array}{c}\text { Ties. } \\
\text { kr. }\end{array}$ & $\begin{array}{c}\mathrm{Ne}- \\
\text { ties. } \\
\mathrm{kr} .\end{array}$ & $\begin{array}{c}\text { Ties. } \\
\text { kr. }\end{array}$ & $\begin{array}{c}\mathrm{Ne}- \\
\text { ties. } \\
\mathrm{kr} .\end{array}$ & $\begin{array}{c}\text { Ties. } \\
\text { kr. }\end{array}$ & $\begin{array}{c}\mathrm{Ne}- \\
\text { ties. } \\
\mathrm{kr} .\end{array}$ & $\begin{array}{c}\text { Ties. } \\
\text { kr. }\end{array}$ & $\begin{array}{c}\mathrm{Ne}- \\
\text { ties. } \\
\mathrm{kr} .\end{array}$ \\
\hline $\mathbf{0}$ & $\mathbf{0}$ & $\mathbf{0}$ & $\mathbf{0}$ & 4 & 28 & 2 & $\mathbf{0}$ & $\mathbf{0}$ & 13 & 28 & 6 \\
\hline
\end{tabular}


5. Kreipimasis 2-ojo asmens ịvardžiu tu. Ivardis tu vartojamas kreipiantis i pažįstamus, gerus draugus. $\mathrm{DLKG}^{16}$ nurodoma, kad jis turi familiaraus kreipimosi atspalvị ir yra stačiokiškas kreipiantis ị nepažįstamą bei gerbiamą asmenį. Šiuo įvardžiu 2013 metais kreiptasi nebuvo, kreiptasi tik veiksmažodžio 2-ojo asmens forma. Per pavasario sesiją politikai 2-ojo asmens formą vartojo itin retai. Taip kreiptis $\mathfrak{i}$ kolegą nèra nemandagu ar pernelyg familiaru, paprastai taip kreipiamasi sykiu pasakant ir to asmens vardą, ị kitą politiką kreipiamasi kaip ị draugą arba gerą pažistamą (49 pvz.):

49) Petrai, pristatyk savo kita pasiūlyma (Vydas Gedvilas Petrui Gražuliui, 2013 m. birželio 13 diena, 62 posédis, pavasario sesija).

\section{1 lentele}

\begin{tabular}{|c|c|c|c|c|c|c|c|c|c|c|c|}
\hline \multicolumn{12}{|c|}{ 2-ojo asmens ịvardis $t u$} \\
\hline \multicolumn{4}{|c|}{$1923 \mathrm{~m}}$. & \multicolumn{4}{|c|}{$1990 \mathrm{~m}}$. & \multicolumn{4}{|c|}{$2013 \mathrm{~m}$. } \\
\hline \multicolumn{2}{|c|}{ Rudens s-ja } & \multicolumn{2}{|c|}{$\begin{array}{c}\text { Pavasario } \\
s-j a\end{array}$} & \multicolumn{2}{|c|}{ Rudens s-ja } & \multicolumn{2}{|c|}{$\begin{array}{c}\text { Pavasario } \\
\text { s-ja }\end{array}$} & \multicolumn{2}{|c|}{ Rudens s-ja } & \multicolumn{2}{|c|}{$\begin{array}{c}\text { Pavasario } \\
\text { s-ja }\end{array}$} \\
\hline $\begin{array}{c}\text { Ties. } \\
\text { kr. }\end{array}$ & $\begin{array}{c}\mathrm{Ne}- \\
\text { ties. } \\
\text { kr. }\end{array}$ & $\begin{array}{c}\text { Ties. } \\
\text { kr. }\end{array}$ & $\begin{array}{c}\mathrm{Ne}- \\
\text { ties. } \\
\text { kr. }\end{array}$ & $\begin{array}{c}\text { Ties. } \\
\text { kr. }\end{array}$ & $\begin{array}{l}\mathrm{Ne}- \\
\text { ties. } \\
\text { kr. }\end{array}$ & $\begin{array}{c}\text { Ties. } \\
\text { kr. }\end{array}$ & $\begin{array}{c}\mathrm{Ne}- \\
\text { ties. } \\
\mathrm{kr} .\end{array}$ & $\begin{array}{c}\text { Ties. } \\
\text { kr. }\end{array}$ & $\begin{array}{c}\mathrm{Ne}- \\
\text { ties. } \\
\text { kr. }\end{array}$ & $\begin{array}{c}\text { Ties. } \\
\text { kr. }\end{array}$ & $\begin{array}{c}\mathrm{Ne}- \\
\text { ties. } \\
\text { kr. }\end{array}$ \\
\hline $\mathbf{0}$ & $\mathbf{0}$ & $\mathbf{0}$ & $\mathbf{0}$ & 1 & $\mathbf{0}$ & $\mathbf{0}$ & $\mathbf{0}$ & $\mathbf{0}$ & $\mathbf{0}$ & 5 & $\mathbf{0}$ \\
\hline
\end{tabular}

5.1. Aprèpiamasis mes. Aprèpiamasis ịvardis mes apima ir rašytoją, ir skaitytoją (adresantą ir adresatą) ${ }^{17}$. Seimo nariai vartoja aprèpimaji ivvardị mes, kai skatina politikus tarsi „nuveikti ką kartu“. Šis kreipinys yra iprastas Seimo sakytineje kalboje, kai adresantas susitapatina su adresatais. Taip paprastai kreipiamasi, kai kalbama apie bendrus abiem pusėms dalykus, sprendžiami bendri klausimai, tada vartojama liepiamoji veiksmažodžio forma:

${ }^{16}$ DLKG - Dabartines lietuviu kalbos gramatika. Vilnius: Mokslo ir enciklopedijų leidybos institutas, 2006, p. 256.

${ }^{17}$ Marcinkevičienè, R. Užsakomųjų reklaminių straipsnių tarpasmeninès funkcijos raiška. Respectus philologicus. Nr. 6(11) (2004), p. 56-63. 
50) Prisiminkim tik paskutinị vokiškosios markès kritimą. Jeigu manoma šiais metais tūkstančiui bežemiams duoti žemès, tai leiskime tiems naujakuriams, kurie turès daug vargo, kol isikurs (Vytautas Petrulis, 1923 m. liepos 6 d., 7 posedis, pavasario sesija);

51) Gal išklausykim deputato $M$. Stakvilevičiaus, tada galesime objektyviau spręsti (Aleksandras Abišala, 1990 m. rugsèjo 4 d., 1 posèdis, rudens sesija);

52) Atmindami Jono Pauliaus II paraginima, nebijokime eiti i prieki kurdami drąsią, veržlią, modernią ir tapatuma išsaugojusią Lietuva (posèdžio pirmininkas Vydas Gedvilas, $2013 \mathrm{~m}$. rugsèjo $10 \mathrm{~d}$., 75 posédis, rudens sesija).

Taip pat šiuo ịvardžiu kreipiamasi, kai yra klausiama visų Seime esančių vardu (taip pat ir to asmens, kuris klausia):

53) Dabar klausimas, ar mes be kirtimo tu 11.000 hak. krašto reikalams galésime apsieiti ar ne? (Referentas, $1923 \mathrm{~m}$. liepos $13 \mathrm{~d}$., 14 posédis, pavasario sesija).

54) Ar mes dar naiviai ịsivaizduojam, kad įmonès, ypač monopolistai, nediktuoja kainu?? (V. Terleckas, 1990 m. liepos 13 d., 106 posédis, pavasario sesija);

55) Ar galime pritarti bendru sutarimu komiteto nuomonei? (Seimo Pirmininkas Vydas Gedvilas, 2013 m. spalio 1 d., 82 posédis, rudens sesija).

12 lentele

\begin{tabular}{|c|c|c|c|c|c|}
\hline \multicolumn{5}{|c|}{ Aprèp. mes } \\
\hline \multicolumn{2}{|c|}{$1923 \mathrm{~m}}$. & \multicolumn{2}{c|}{$1990 \mathrm{~m}$. } & \multicolumn{2}{c|}{$2013 \mathrm{~m}}$. \\
\hline Ruden s-ja & $\begin{array}{c}\text { Pavasario } \\
\text { s-ja }\end{array}$ & Rudens s-ja & $\begin{array}{c}\text { Pavasario } \\
\text { s-ja }\end{array}$ & Rudens s-ja & $\begin{array}{c}\text { Pavasario } \\
\text { s-ja }\end{array}$ \\
\hline 137 & $\mathbf{1 4 5}$ & $\mathbf{6 4 4}$ & $\mathbf{1 4 5 8}$ & $\mathbf{9 8 0}$ & $\mathbf{1 7 9 2}$ \\
\hline
\end{tabular}

5.2. Tamsta ir tamstos. Ivardis tamsta vartojamas retai, dažniausiai šị îvardị vartoja senesnès kartos žmonès, kreipdamiesi ị nepažịs- 
tamą asmenị oficialiai arba ị pažįstamą su pagarba, nefamiliariai. Jaunesnès kartos žmonès suvokia jị kaip archajišką ir nevartoja. Tamsta turi daugiskaitos formas: tamstos, savo reikšme artimos $j \bar{u} s^{18}$. Atliktas tyrimas rodo, kad ivvardis tamsta / tamstos buvo vartojamas tik 1923 ir 1990 metais. Šiuo ịvardžiu 1923 metais buvo kreiptasi tada, kai norèta perduoti naują informaciją. Ši informacija dažniausiai buvo neigiamo turinio:

56) Tamstos atsimenat gerai, kaip buvo rašyta laikraščiuose, kad vienas mūsu valdininkas, pralošęs gera mūsų valdžios pinigų sumą, turejo bègti iš tèvynès pasislèpt (Rudolfas Kinderis, $1923 \mathrm{~m}$. liepos $6 \mathrm{~d}$., 7 posédis, pavasario sesija).

Idomu tai, jog, kai kreipiamasi šiuo ịvardžiu ị vieną asmenị, dažniausiai tas asmuo yra kritikuojamas ir išsakomos griežtos bei aštrios pastabos, jam prieštaraujama, šiuo atveju toks kreipinys atrodo labai asmeniškas:

57) Aš apie atstovę Purèniene galiu pasakyt. Tamsta ilga laika laižei kunigų slenksčius ir paskui tamsta tapai kunigu priešininke (Adomas Vilimas Liūdai Purènienei, 1923 m. liepos 13 d., 14 posédis, pavasario sesija).

1990 metu rudens sesijos metu politikai kreipinio konstrukcija tamsta + daiktvaradinis ivardijimas kreipèsi 5 kartus: kreipiamasi tada, kai norima adresato ko nors paklausti, kreipiamasi prieš pradedant kalbą. Ivardis tamsta / tamstos vartojamas su daiktavardiniu ivvardijimu, nusakančio asmens einamas pareigas Seime. Tokiu įvardžiu kreipèsi vyresni Seimo nariai, pavyzdžiui, Vilmantas Rupeika:

58) Jeigu sutiksite atsakyti, tamsta Pirmininke, paklausiu apie jūsu minèta korupcija (Benediktas Vilmantas Rupeika, 1990 m. rugsëjo 4 d., 1 posédis, rudens sesija).

5.3. Jūs (dgs.) Tai ịprastas ir vienintelis kreipinys kreipiantis participiniu ịvardžiu daugiau nei $\mathfrak{i}$ vieną asmenị. Visais atvejais kreiptasi $\mathfrak{i}$ Seimo narius ar ị Seimą atvykusius svečius:

18 Dabartinés lietuviu kalbos gramatika. Vilnius: Mokslo ir enciklopedijų leidybos institutas, 2006, p. 256. 
59) Jūs klausiat kaip pasibaigè. Aš turiu jums pasakyt, kad darbininkus apskunde ne dvarininkas, o milicijos vadas. Leiskite man taip suprasti: nejaugi 30 margu gali duoti tik 38 centnerius ir dvi karvi išlaikyt? (Jeronimas Plečkaitis kreipiasi ị Seimo narius, 1923 m. rugsejjo 18 d., 25 posédis, rudens sesija);

60) Aš neketinau pradèti mūsų sesijos kelioniu ispūdžiais ar kokiomis nors išvadomis, susijusiomis su mano vizitais Danijoje ir Norvegijoje. Galbūt apie tai bus galima pakalbèti atskirai, jeigu jūs rasite tam laiko ir specialiai pageidausite (Vytautas Landsbergis, 1990 m. rugsejjo 4 d., 1 posédis, rudens sesija);

61) Gerbiamieji kolegos, gerbiamieji V. Šadreikos artimieji, leiskite man Nepriklausomybes Akto signataro, Seimo nario, sveikatos apsaugos ministro V. P. Andriukaičio vardu perskaityti jo parengta kalba V. Šadreikai atminti (Irena Šiaulienè, 2013 m. birželio 20 d., 66 posèdis, pavasario sesija).

5.4. Jūs (vns.) Jūs reikšme „tu“ vartojamas kreipiantis i pažįstamą arba mažai pažìstamą, vyresnị bei gerbiamą asmenị, taip pat ị pažįstamą oficialiai (santykis tarp viršininko ir pavaldinio, kartais tarp bendradarbių). Jūs reikšme „tu“ vartojamas su veiksmažodžių daugiskaitos (morfologinis derinimas), o vardažodžių - su vienaskaitos formomis (reikšminis derinimas) ${ }^{19}$.

1923 metais jūs (vns.) buvo labai retas, aptikti tik keli atvejai. Dažniausiai vietoj šio ịvardžio buvo vartojamas tamsta.

62) Demagogai kaip tik jūsu pusèje sèdi (Pranas Radzevičius Justinui Staugaičiui, 1923 m. liepos 13 d., 14 posèdis, pavasario sesija).

1990 ir 2013 metų parlamentiniame diskurse iprasta kreiptis ìvardžiu jūs ir įvardžio daugiskaitos forma, taip palaikomi pagarbūs ir oficialūs santykiai (63 pvz.), nors kreipiamasi ir tokiose situacijose, kai adresatui dèl ko nors prieštaraujama arba sakoma pastaba (64 pvz.):

${ }^{19}$ Ten pat, p. 256. 
63) Žodžiu, jūs pageidaujate dar karta pakartoti tą, kuris buvo parengtas mūsu darbo grupès, ir tą, kuri rengé Centro frakcijos iniciatyvine grupe (Liudvikas Sabutis Lionginui Šepečiui, 1990 m. rugsèjo 5 d., 3 posèdis, rudens sesija);

64) Nekalbékite netiesos, paskaitykite projekta (Rimantas Jonas Dagys Kęstučiui Daukšiui, 2013 m. liepos 2 d., 72 posédis, pavasario sesija).

13 lentele

\begin{tabular}{|c|c|c|c|c|c|c|c|c|c|c|c|}
\hline \multicolumn{12}{|c|}{ Tamsta / tamstos } \\
\hline \multicolumn{4}{|c|}{$1923 \mathrm{~m}}$. & \multicolumn{4}{|c|}{$1990 \mathrm{~m}}$. & \multicolumn{4}{|c|}{$2013 \mathrm{~m}}$. \\
\hline \multicolumn{2}{|c|}{ Rudens s-ja } & \multicolumn{2}{|c|}{$\begin{array}{c}\text { Pavasario } \\
\text { s-ja }\end{array}$} & \multicolumn{2}{|c|}{ Rudens s-ja } & \multicolumn{2}{|c|}{$\begin{array}{c}\text { Pavasario } \\
\text { s-ja }\end{array}$} & \multicolumn{2}{|c|}{$\begin{array}{c}\text { Rudens } \\
\text { s-ja }\end{array}$} & \multicolumn{2}{|c|}{$\begin{array}{l}\text { Pavasa- } \\
\text { rio s-ja }\end{array}$} \\
\hline $\begin{array}{c}\text { Tams- } \\
\text { tos }\end{array}$ & $\begin{array}{c}\text { Tams- } \\
\text { ta }\end{array}$ & $\begin{array}{c}\text { Tams- } \\
\text { tos }\end{array}$ & $\begin{array}{c}\text { Tams- } \\
\text { ta }\end{array}$ & $\begin{array}{c}\text { Tams- } \\
\text { tos }\end{array}$ & $\begin{array}{c}\text { Tams- } \\
\text { ta }\end{array}$ & $\begin{array}{c}\text { Tams- } \\
\text { tos }\end{array}$ & $\begin{array}{c}\text { Tams- } \\
\text { ta }\end{array}$ & & & & \\
\hline 2 & 1 & 104 & 52 & 2 & 3 & 0 & 0 & 0 & 0 & 0 & 0 \\
\hline
\end{tabular}

14 lentele

\begin{tabular}{|c|c|c|c|c|c|c|c|c|c|c|c|}
\hline \multicolumn{12}{|c|}{ Jūs (dgs. / vns.) } \\
\hline \multicolumn{4}{|c|}{$1923 \mathrm{~m}}$. & \multicolumn{4}{|c|}{$1990 \mathrm{~m}}$. & \multicolumn{4}{|c|}{$2013 \mathrm{~m}}$. \\
\hline \multicolumn{2}{|c|}{ Rudens s-ja } & \multicolumn{2}{|c|}{$\begin{array}{c}\text { Pavasario } \\
\text { s-ja }\end{array}$} & \multicolumn{2}{|c|}{ Rudens s-ja } & \multicolumn{2}{|c|}{$\begin{array}{c}\text { Pavasa s-ja } \\
\text { rio }\end{array}$} & \multicolumn{2}{|c|}{ Rudens s-ja } & \multicolumn{2}{|c|}{$\begin{array}{c}\text { Pavasario } \\
\text { s-ja }\end{array}$} \\
\hline \begin{tabular}{|c|} 
Jūs \\
(dgs.)
\end{tabular} & \begin{tabular}{|c} 
Jūs \\
(vns.)
\end{tabular} & \begin{tabular}{|c|} 
Jūs \\
(dgs.)
\end{tabular} & \begin{tabular}{|c} 
Jūs \\
(vns.)
\end{tabular} & $\begin{array}{c}\text { Jūs } \\
\text { (dgs.) }\end{array}$ & \begin{tabular}{|c} 
Jūs \\
(vns.)
\end{tabular} & $\begin{array}{c}\text { Jūs } \\
\text { (dgs.) }\end{array}$ & \begin{tabular}{|c|} 
Jūs \\
(vns.)
\end{tabular} & $\begin{array}{l}\text { Jūs } \\
\text { (dgs.) }\end{array}$ & \begin{tabular}{|c} 
Jūs \\
(vns.)
\end{tabular} & \begin{tabular}{|c|} 
Jūs \\
(dgs.)
\end{tabular} & \begin{tabular}{|c} 
Jūs \\
(vns.)
\end{tabular} \\
\hline 155 & 5 & 105 & 2 & 1000 & 889 & 725 & 963 & 987 & 726 & 1051 & 800 \\
\hline
\end{tabular}

\section{Išvados}

Politikai vieni $\mathfrak{i}$ kitus kreipèsi daiktavardiniais kreipiniais, reiškiančiais Seime einamų pareigų pavadinimus, moksliniais vardais, 1990 ir 2013 metais - dažnai kreipiniais kolega / - e / -os. Neretai prieš einamų pareigų pavadinimus eina pagarbūs kreipiniai gerbiamasis / -oji / -ieji arba pone. Kreipdamiesi i daugumą, Seimo nariai neretai vartodavo 
būdvardiškajji dalyvị gerbiamieji. 1990 ir 2013 metais kreiptasi būdvardžiais mielieji / brangieji. Daiktavardinis ịvardijimas + pavardè būdingas tik 1923 metų Seimui. Vardu ir pavarde iprasta kreiptis tik 1990 ir 2013 metų Seime, prieš tokị kreipinị kartais eina pareigų pavadinimas arba pagarbusis kreipinys gerbiamasis / pone. Itin formalus kreipinys + daiktavardinis ịvardijimas + būdvardiškasis dalyvis + pavardè vartotas tik 1990 metais. Visais tiriamais laikotarpiais kreiptasi aprejpiamuoju mes, jūs (vns. ir dgs.). Ivardžiai tamsta / -os būdingas tik 1923 ir 1990 metų Seimui.

Kalba viešajame sakytiniame diskurse iš tiesų tampa demokratiškesnè - palyginti su 1923 ir 1990 metų duomenimis, 2013 metais politikai nevengia kreiptis vieni $\mathfrak{i}$ kitus vardais, kartais prieš vardą eina pagarbusis kreipinys gerbiamasis / -oji. Taip pat vartojami įvairesni kreipiniai, retai, bet kartais kreipiamasi 2-ojo asmens veiksmažodžio forma, pavyzdžiui, Gerbiamasis Juliau, neklaidink tautos (Bronius Bradauskas Juliui Sabutauskui). Ivardžiu tu Seimo nariai 2013 m. vieni i kitus nesikreipè.

Vienoki ar kitoki vartojimą lemia konteksto oficialumas - 1923 ir 1990 metais Seimo nariai labiau atsižvelgdavo ị kontekstą, i darbo vietą, 2013 metais kreipimosi tendencijos iš neoficialios aplinkos yra perkeliamos ị oficialią viešąją erdvę.

Palyginti su 1923 ir 1990 metais, 2013 metais nevengiama tiesioginio ir asmeniškesnio santykio su adresatu. 1923 metais dažniausiai buvo kreiptasi netiesiogiai, 1990 metais kreipimosi tendencijos pradèjo krypti tiesioginio santykio užmezgimo su adresatu link. 


\title{
PARLIAMENTARY DISCOURSE ANALYSIS: DEVELOPMENT OF THE EXPRESSION OF ADDRESS
}

\author{
Zoja Petrošıūté
}

\section{Summary}

Keywords: parliamentary discourse; addresses; pronouns; politician speech; Parliament.

The subject of this article is address terms politians use in oficial public sphere - in 1923, 1990 and 2013 year Lithuanian Parliament. It is supposed that in the contemporary Parliamentary public sphere politicians are tend to use more informal addresses. The study result showed that address terms typical for private sphere, tend to penetrate the public area in 2013 year. Comparing the data of three periods, we can notice that in contemporary parliamentary discourse politians are tend to use names and second person (sg.) verbs, though they do not use second person pronouns (sg.). Also politicians are tend to use more direct addresses.

Iteikta 2014 m. spalio 3 d. 